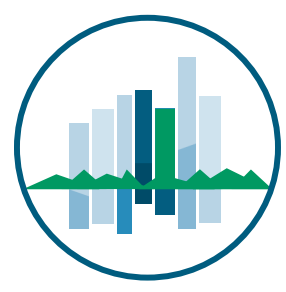

True Smart and Green City?

8th Conference of the

International Forum on Urbanism

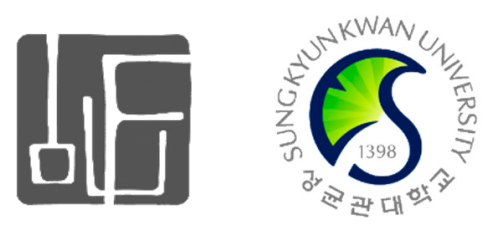

Conference Proceedings Paper

\title{
Study On The Smart Growth Resource-Based City In China: A Case Study Of Renewing Cities
}

\author{
Ruiyin Dou *, Xuemin Liu, Qiang Li \\ College of Resource Science and Technology, Beijing Normal University, 100875 Beijing, China \\ * Author to whom correspondence should be addressed; E-mail: douruiyin0816@163.com
}

\begin{abstract}
The resource-based city shows a gradually decline behind the external prosperity in China. It has been identified that there were 262 resource-based cities in China. According to the different stages of development, the resource-based cities were divided into four types: growing, maturing, exhausting and renewing. Currently, 23 of them which have entered the exhausted post-transition phase of resource were called renewing cities. Thus, the focus of this paper is on the smart growth of renewing cities, whose core elements can be extracted from the essential characteristics showed in the process. Based on the thought of "smart growth" and aspects of "moderate exploitation", "green ecology" and "social comfort", the analytic framework of "smart growth", with 9 goals and 40 sets of variables relationships established, is formed. According to the statistical description and analysis of the existing data, in 40 sets of variables, there are 22 sets in line with the "smart growth" requirements; while 15 sets not; and another 3 sets cannot be judged. Finally, based on the results of the analysis, the path of "smart growth" for renewing city can be explained from aspects of city infrastructure supply, land development and utilization, energy saving and emission reduction, environmental protection and city agglomeration promotion, which are the key ares that government should focus on as well.
\end{abstract}

Keywords: Resource-based city; renewing city; smart growth; moderate exploitation; green ecology; social comfort

\section{Introduction}

In December 2013, the state council announced the «sustainable development plan of resource-based city in China (2013-2020)». Currently, 23 of resource-based cities which have entered the exhausted 
post-transition phase of resource were called renewing cities. Economic development of renewing cities depend basically out, Social and economic development into the healthy track, is the first batch of the transformation of economic development mode of resource-based cities ${ }^{[1-2]}$. Renewing cities across China from northeast to southwest provinces, the resource type also covers oil and gas, coal, metal and so on. Renewing cities have made a great contribution to economic development, at the same time, the development of the city itself in such aspects as economy, environment and society have paid a heavy price. Renewing cities have serious historical issues, it's reported that there are $7 \times 10^{7} \mathrm{~m}^{3}$ shantytown need to be overhauled, and $14 \times 10^{4} \mathrm{hm}^{2}$ subsidence area need to be restored, The number of unemployed miners up to $6 \times 10^{5}$ people, the number of urban minimum insurance more than $1.8 \times 10^{6}$ people. In addition, the industry development have a strong dependence on resource, Mining industry accounts for secondary industry accounted for more than $20 \%$ and a series of serious problems. Renewing cities have to choose industrial upgrading, enterprise restructuring in driving the development of urban economy when they face resources drying up, trying to get rid of resource constraints on urban economy, reduce environmental pressure ${ }^{[3-4]}$.

Sustainable development of the renewing cities is very tough determined by their character of particularity. So it is necessary to evaluate its current situation of urban development, in order to grasp the overall development of sustainable cities. In this paper, we based on the thought of smart growth and aspects of moderate exploitation, green ecology and social comfort, the analytic framework of smart growth. According to the statistical description and analysis of the existing data, the test results can indicate the future direction for the development of government policies, among variables are not exactly in line with the future of the relationship between smart growth policies should focus on and adjust the focus areas.

\section{The smart growth of renewing city}

Smart growth concept is the result of urban planning, it aims to solve the urban spread bring serious resources, environment, economy, social issues, focusing on the urban development and planning in the formulation and implementation of policies and regulations, the urban land use in the process of urbanization, space layout, and other market forces role in the field of administrative intervention, through the planning of compact community, give full play to the effectiveness of the existing infrastructure, to provide more diversified traffic and housing options, the control system for the urban spread type development. In general, smart growth is through a series of policy instruments and means of management, make urban space comprehensive performance of the optimal ${ }^{[5]}$. Under the dual pressures of urban industrial restructuring and resource and environmental constraints, by implementing smart growth in order to pursue urban optimal space utilization efficiency is the important method and content to achieve sustainable development for renewing cities.

\subsection{The research object and the selection of the data}

In this article, rely on the «sustainable development plan of resource-based city in China (20132020)», 23 of resource-based cities which were called renewing cities, 16 of renewing cities are local administrative region, they are Tangshan, Baotou, Anshan, Panjin, Huludao, Tonghua, Xuzhou, Suqian, Maanshan, Zibo, Linyi, Luoyang, Nanyang, Aba Tibetan and qiang autonomous prefecture, Lijiang, 
Zhangye; 4 of renewing cities are county, they are Xiaoyi, Dashiqiao, Longkou, laizhou; 3 of renewing cities are county town, they are Anyang, Yunyang, Shangri-la, respectively. In this paper, the data mainly from „China city statistical yearbook“(2013), China's economic and social development of statistical database, Statistical Communique on the 2012 national economy and social development,"City statistical yearbook" (2013). Considering the data integrity, availability and accuracy, this paper only select regional administrative division 16 renewable cities as the research object to study the condition of smart growth.

\subsection{Smart growth index selection}

Based on the scholars of the Lincoln institute of land policy on the basis of the need to achieve the goal of smart growth ${ }^{[6]}$, combined with the actual situation of the regeneration of cities in our country, the regeneration of cities smart growth summarized into three categories, a total of nine goals, as shown in table 1.

Table 1. The category, target index selection of smart growth.

\begin{tabular}{|c|c|c|c|}
\hline & Target & Study content & $\begin{array}{c}\text { Index selection } \\
\end{array}$ \\
\hline & & $\begin{array}{l}\text { The relationship between infrastructure } \\
\text { and population }\end{array}$ & $\begin{array}{l}\text { Per capita area of paved roads in City, } \\
\text { Municipality's total population }\end{array}$ \\
\hline & & $\begin{array}{l}\text { The relationship between infrastructure } \\
\text { and industry structure }\end{array}$ & $\begin{array}{l}\text { Per capita area of paved roads in City, } \\
\text { Secondary industry and tertiary industry } \\
\text { proportion }\end{array}$ \\
\hline & & $\begin{array}{l}\text { The relationship between infrastructure } \\
\text { and employment density }\end{array}$ & $\begin{array}{l}\text { Per capita area of paved roads in City, } \\
\text { Employment density built-up area }\end{array}$ \\
\hline & $\begin{array}{l}\text { Obect1 : } \\
\text { Promote compact } \\
\text { development }\end{array}$ & $\begin{array}{l}\text { The relationship between land } \\
\text { development and population }\end{array}$ & Built-up area, Municipality's total population \\
\hline & & $\begin{array}{l}\text { The relationship between land } \\
\text { development and industry structure }\end{array}$ & $\begin{array}{l}\text { Built-up area, Secondary industry and tertiary } \\
\text { industry }\end{array}$ \\
\hline & & $\begin{array}{l}\text { The relationship between land } \\
\text { development and employment density }\end{array}$ & $\begin{array}{l}\text { Built-up area, Employment density built-up } \\
\text { area }\end{array}$ \\
\hline \multirow[t]{8}{*}{$\begin{array}{l}\text { Moderate } \\
\text { exploitati } \\
\text { on }\end{array}$} & & $\begin{array}{l}\text { The relationship between land } \\
\text { development and income level }\end{array}$ & Built-up area, Per capita disposable income \\
\hline & & $\begin{array}{l}\text { The relationship between the number of } \\
\text { public transport supply and population }\end{array}$ & $\begin{array}{l}\text { Number of public transportation vehicles per } 10 \\
000 \text { population, Municipality's total population }\end{array}$ \\
\hline & $\begin{array}{l}\text { Object2 : Encourage } \\
\text { public transport }\end{array}$ & $\begin{array}{l}\text { The relationship between the number of } \\
\text { public transport supply and the population } \\
\text { density }\end{array}$ & $\begin{array}{l}\text { Number of public transportation vehicles per } 10 \\
000 \text { population, City area population density }\end{array}$ \\
\hline & & $\begin{array}{l}\text { The relationship between the public } \\
\text { transport carrying capacity and population }\end{array}$ & $\begin{array}{l}\text { Total annual volume of passengers } \\
\text { transported by buses and trolley buses, } \\
\text { Municipality's total population }\end{array}$ \\
\hline & & $\begin{array}{l}\text { The relationship between the public } \\
\text { transport carrying capacity and the } \\
\text { population density }\end{array}$ & $\begin{array}{l}\text { Total annual volume of passengers } \\
\text { transported by buses and trolley buses, City } \\
\text { area population density }\end{array}$ \\
\hline & $\begin{array}{l}\text { Object3: } \\
\text { Provide affordable } \\
\text { housing }\end{array}$ & $\begin{array}{l}\text { The relationship between the urban } \\
\text { housing land area and population }\end{array}$ & $\begin{array}{l}\text { Area of land used for living, Municipality's } \\
\text { total population }\end{array}$ \\
\hline & $\begin{array}{l}\text { Object } 4: \\
\text { Protection of resources } \\
\text { and environmental } \\
\text { guality }\end{array}$ & $\begin{array}{l}\text { The relationship between the green } \\
\text { covered area and population }\end{array}$ & $\begin{array}{l}\text { Green covered area as of completed areas, } \\
\text { Municipality's total population }\end{array}$ \\
\hline & & $\begin{array}{l}\text { The relationship between the green } \\
\text { covered area and land development }\end{array}$ & $\begin{array}{l}\text { Green covered area as of completed areas, } \\
\text { Built-up area }\end{array}$ \\
\hline $\begin{array}{l}\text { Green } \\
\text { ecology }\end{array}$ & $\begin{array}{l}\text { Object5 : } \\
\text { Energy saving }\end{array}$ & $\begin{array}{l}\text { The relationship between cities output and } \\
\text { energy consumption }\end{array}$ & $\begin{array}{l}\text { Total urban GDP, The city's total water } \\
\text { electricity and natural gas consumption }\end{array}$ \\
\hline
\end{tabular}




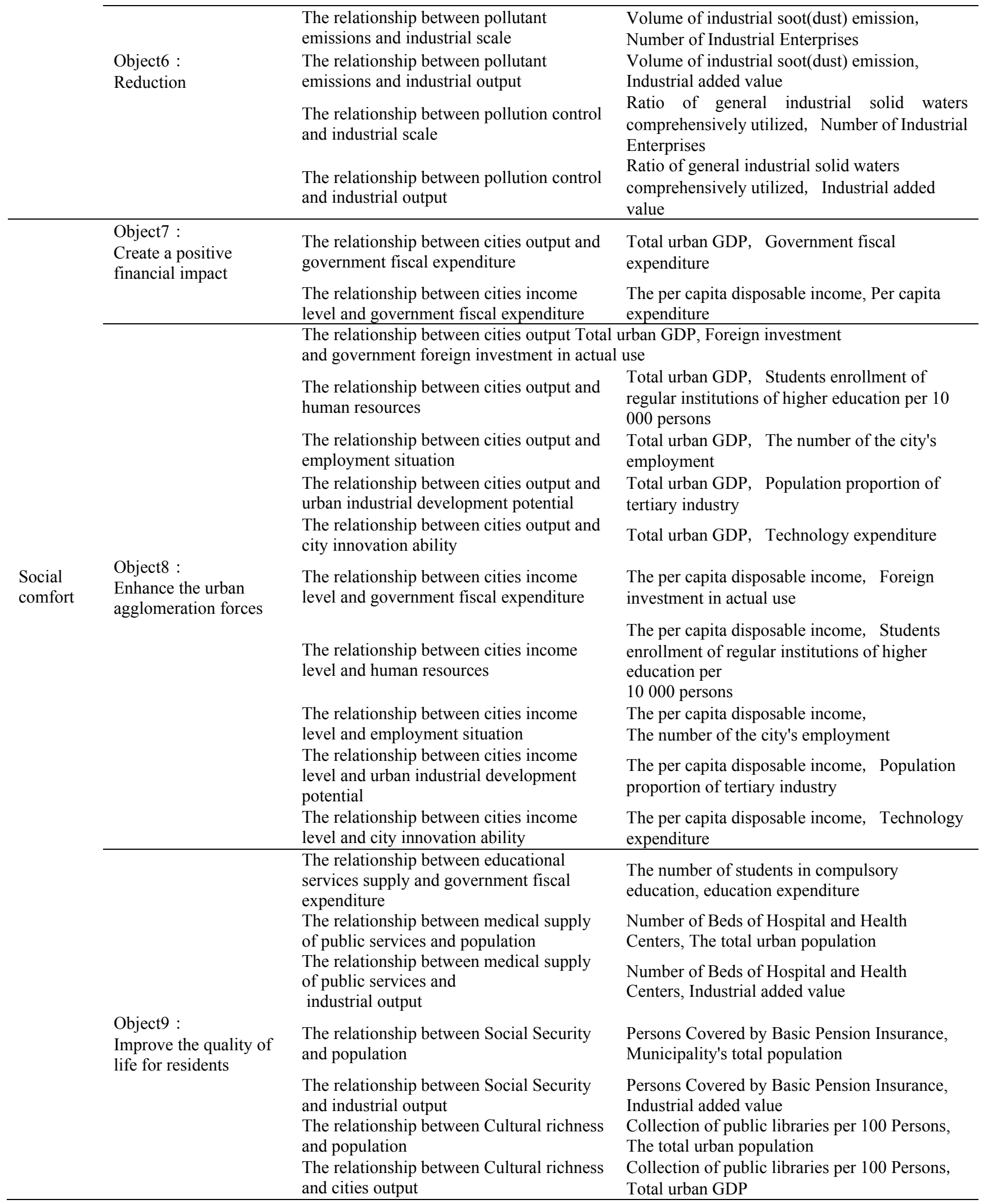

\section{Analysis of smart growth for renewing city}

\subsection{Moderate exploitation}

The goals of moderate development include 3 principles: Firstly, promote compact development. Emphasizing the rational exploitation of land and infrastructure moderate supply; secondly, encourage 
public transport. Priority to the development of public transport; Thirdly, Improve living conditions which is including provide affordable housing.

\subsubsection{Promote compact development}

To investigate renewing cities' compact development, we should consider whether it is reasonable development and utilization of infrastructure. In this paper, we use per capita area of paved roads in City, municipality's total population show The relationship between infrastructure and population (Figla), use per capita area of paved roads in city, secondary industry and tertiary industry proportion show the relationship between infrastructure and industry structure (Figure 1b), use per capita area of paved roads in city, employment density built-up area show the relationship between infrastructure and employment density (Figure 1c). On the basis of correlation analysis, Three groups of variables' $\mathrm{R}^{2}$ respectively are $0.002,0.205,0.075$, which implies that there are no significant correlation between the number of infrastructure supply and population size, industry structure, employment density. Thus, in the Chinese city of renewing supply infrastructure has not been significantly affected urban population size, industry structure, employment density.

It is noteworthy that the goals of smart growth emphasized the principle which is in the premise of meeting the population growth in demand, as far as possible cost savings. Urban population should be the user a variety of infrastructure, population size should be an important basis for determining the amount of infrastructure supply, both of the positive correlation should exist, but the article does not show a significant correlation proved in 15 regenerative cities (Aba Tibetan and Qiang Autonomous Prefecture of missing data) related to the reality of the data, does not conform the spirit of the smart growth.

Figure 1. The relationship between infrastructure and related variables.

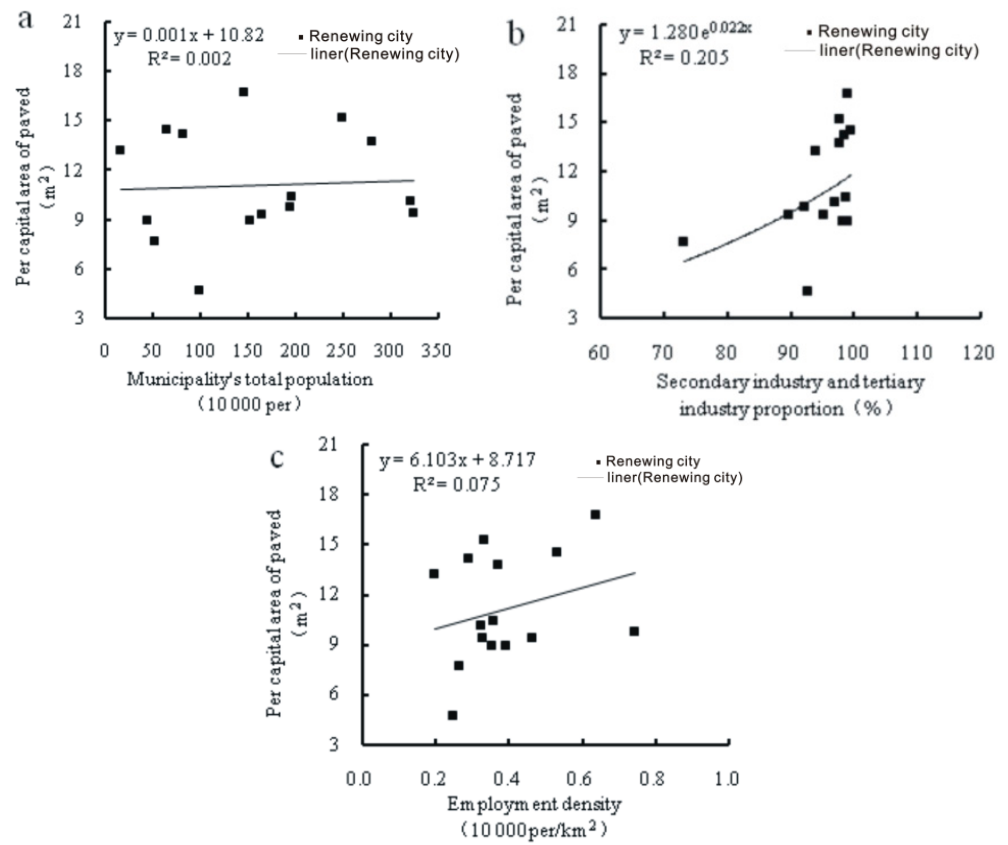


This paper use built-up area, municipality's total population show the relationship between land development and population (Fig2a), use built-up area, secondary industry and tertiary industry show The relationship between land development and industry structure (Figure 2b), use built-up area, employment density built-up area show the relationship between land development and employment density (Figure 2c), built-up area, per capita disposable income show the relationship between land development and income level (Figure 2d). On the basis of correlation analysis, four groups of variables' $\mathrm{R}^{2}$ respectively are $0.785,0.251,0.08,0.177$, only the relationship between built-up area and municipality's total population through the test of significance of $99 \%$. Therefore, The relationship between land development and population show a positive correlation relationship. We can see that the land development influenced by the urban population scale significantly of renewing cities, a certain scale of population can accelerate the land development and promote the development of renewing cities.

The research results show that the relationship between land development and population in line with smart growth. It is worth noting that our government should strictly control land development in case of the waste of land resources.

Figure 2. The relationship between built-up area and related variables.
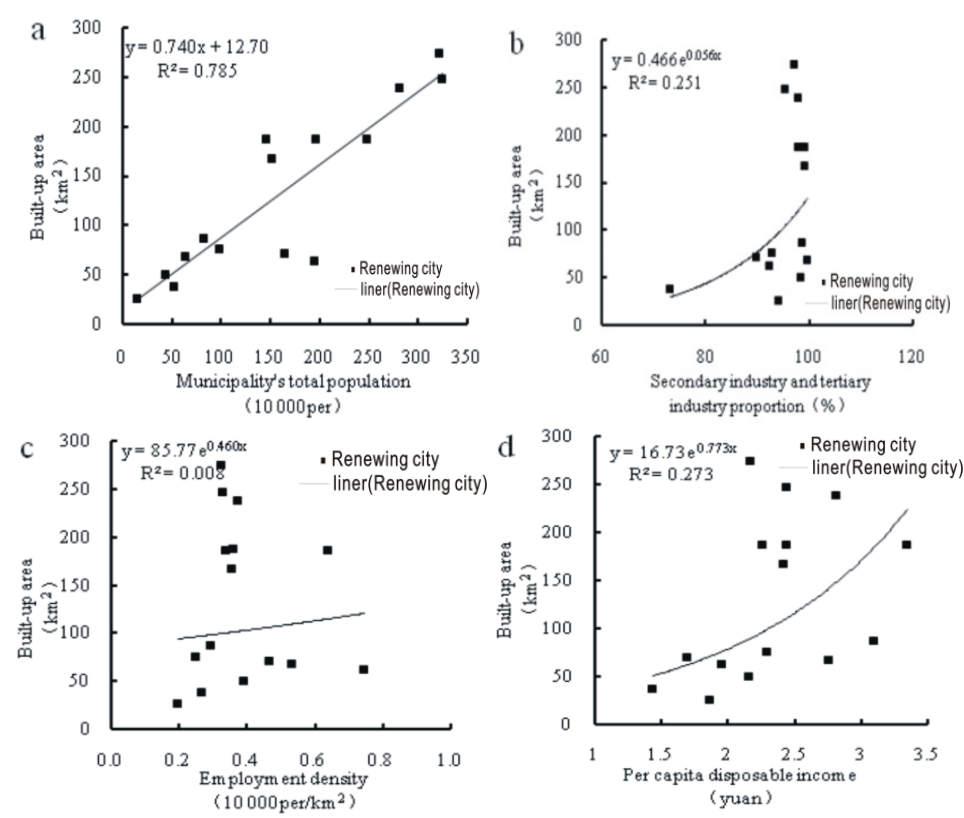

\subsubsection{Encourage public transport}

The principle of smart growth is encouraging the development of public transport. Urban should raise citizens' frequency of use of public transport by the convenient and comfortable public transportation system.

This paper use number of public transportation vehicles per 10000 population, municipality's total population show the relationship between the number of public transport supply and population (Fig3a), use number of public transportation vehicles per 10000 population, city area population density show The relationship between the number of public transport supply and the population density (Figure 3b). On the basis of correlation analysis, two groups of variables' $\mathrm{R}^{2}$ respectively are $0.079,0$, none groups 
of variables pass the significance test. Therefore, there is no relationship between public transport supply and population, there is no relationship between public transport supply and population density.

The research shows a result that different from the principle of smart growth. The public transport supply cannot matched the density of population which were caused the carrying capacity will be reduced ${ }^{[7]}$.

Figure 3. The relationship between number of public transportation vehicles per 10000 population and related variables.
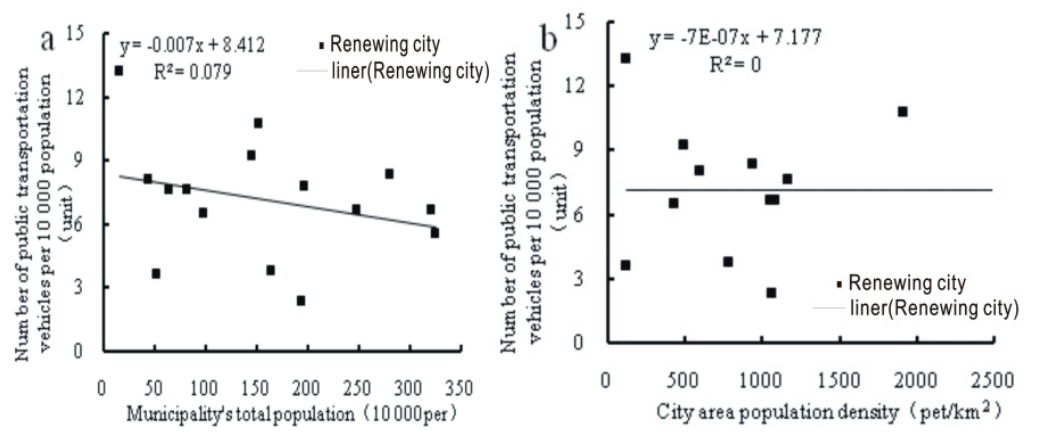

Then, we use total annual volume of passengers transported by buses and trolley buses, municipality's total population show The relationship between the public transport carrying capacity and population (Fig4a), total annual volume of passengers transported by buses and trolley buses, city area population density show the relationship between the public transport carrying capacity and the population density (Figure 4b). On the basis of correlation analysis, two groups of variables' $\mathrm{R}^{2}$ respectively are 0.505 , 0.411 , all the two groups of variable acess the significant test $90 \%$. It is concluded that each increase of the city area population of ten thousand people, the year the bus traffic increases 600000 times. Relying on the increase of population density in the renewing cities, the annual total volume of bus also assumes the exponential growth. As the city population distribution concentration degree of upgrading, public traffic carrying capacity corresponding increase which accords in line with smart growth on public transport priority advocate.

Figure 4. The relationship between total annual volume of passengers transported by buses and trolley buses and related variables.

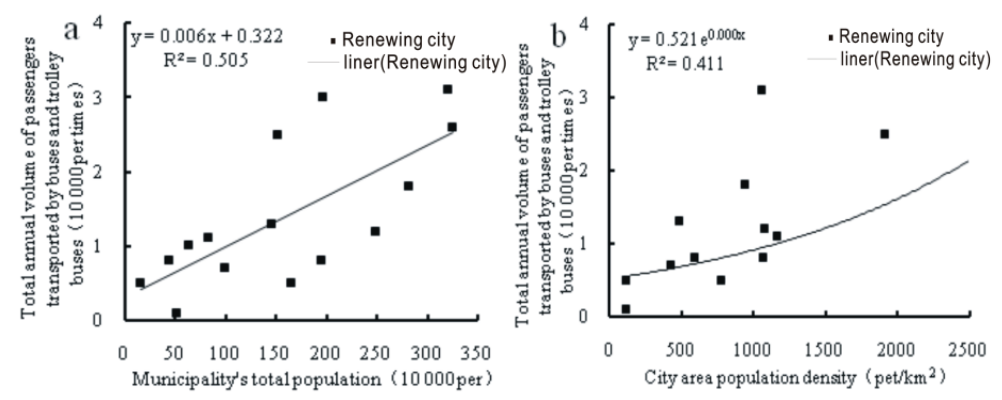




\subsubsection{Provide affordable housing}

Smart growth requirements provide affordable housing through guiding the land exploitation and utilization, providing the scope of ability to pay within the housing for different income families. This paper use area of land used for living, municipality's total population show the relationship between the urban housing land area and population. On the basis of correlation analysis, the group of variable' $\mathrm{R}^{2}$ is 0.639 , through the significant test $99 \%$. Therefore, the urban housing land area and population show a positive relationship of the renewing cities in china. According to statistics, the city's population increased by 10000 , the corresponding residential land area increased $0.19 \mathrm{~km}^{2}$.It is worth noting that we can't judge the degree of the land development appears mutation points so that the government should be strictly planning to prevent violation of smart growth mode of land use.

Figure 5. The relationship between area of land used for living and related variables.

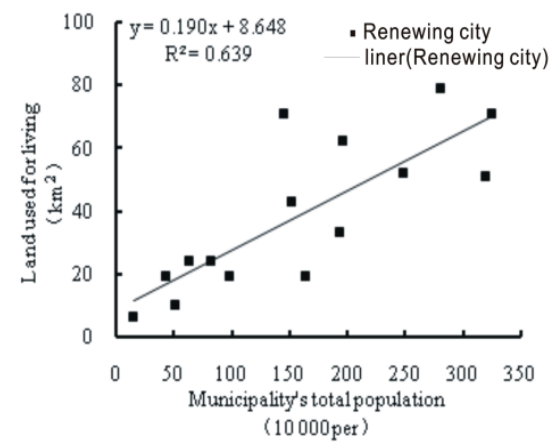

\subsection{Green ecology}

The goal of Smart growth is to coordinate the development of economy, environment, resources and society. It's more important to the renewing cities to protect environment and rational use of resources which is one of the critical key factors for transformation of renewing cities successfully.

\subsubsection{Protection of resources and environmental quality}

In considering the relationship between land expansion, city construction and city ecological environment of the renewing cities, this paper use Green covered area as of completed areas, municipality's total population show the relationship between the green covered area and population (Fig6a), use green covered area as of completed areas, guilt-up area show the relationship between the green covered area and land development (Figure 6b). On the basis of correlation analysis, two groups of variables' $\mathrm{R}^{2}$ respectively are $0.028,0.112$, two groups of variables all did not pass the significance test. Therefore, there is no relationship between the green covered area and population, there is no relationship between the green covered area and land development. Thus, the green area of renewing cities have not been significantly affected by the scale of population and land development. In other words, no matter the city population scale development to what extent, regardless of how the city expansion, are not at the expense of city green space for the price, which is consistent with the smart growth requirements on environmental protection. 
Figure 6. The relationship between green covered area of completed areas and related variables.
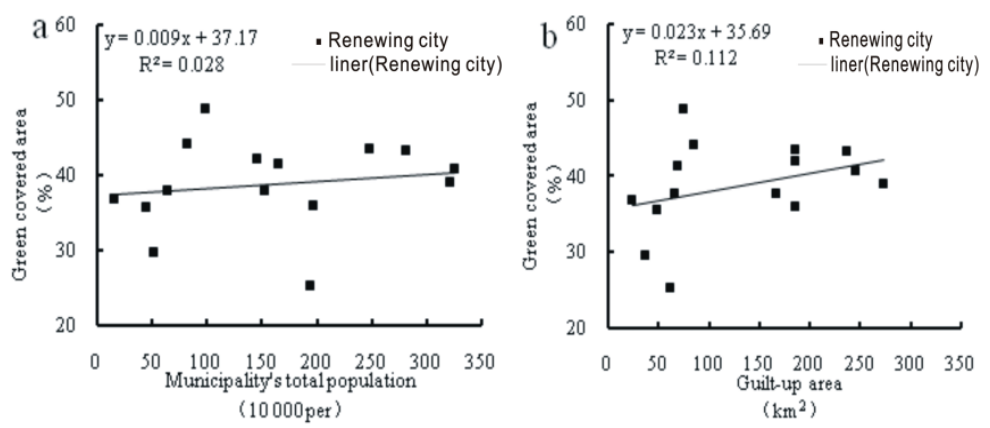

\subsubsection{Energy saving}

In considering the regeneration type city energy saving is in accordance with the smart growth principle, this paper use the total urban GDP and the city's total water consumption show the relationship between cities output and energy consumption(Fig7a), use the total urban GDP and the city's total gas consumption show the relationship between cities output and energy consumption (Figure 7b), use the total urban GDP and the city's total electricity consumption show the relationship between cities output and energy consumption (Fig7C). On the basis of correlation analysis, three groups of variables' $\mathrm{R}^{2}$ respectively are $0.637,0.581,0.871$, through the significant test $99 \%$. Therefore, there are positive correlation between the total GDP and total energy consumption. Thus, the output of the renewing city increased with the increase of the main energy consumption, which is not in accordance with the spirit of smart growth.

Figure.7. The relationship between Gross Domestic Product and related variables.
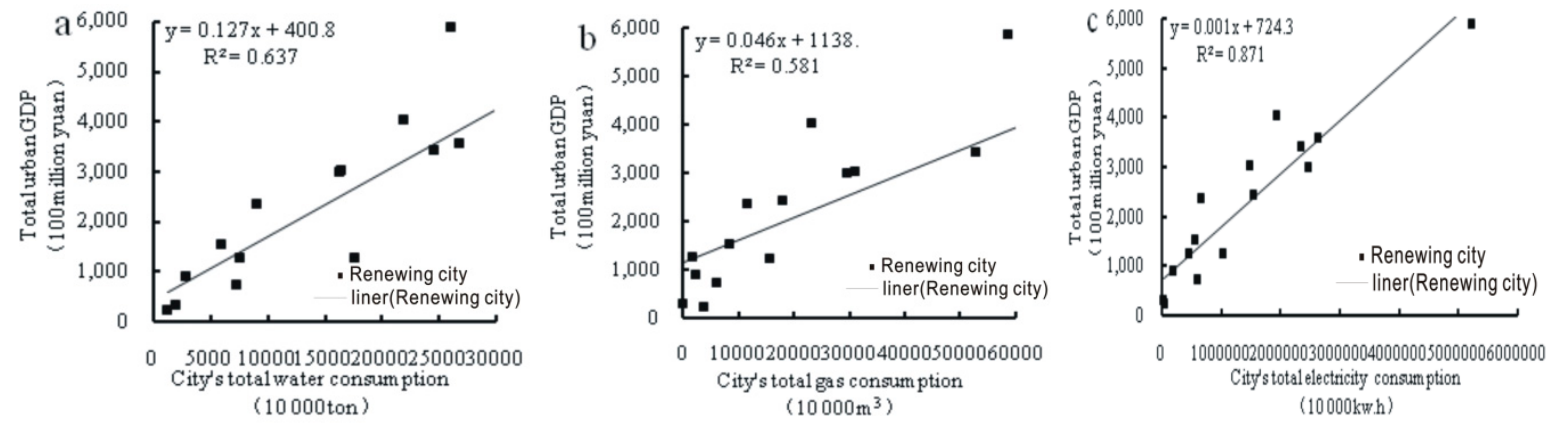

\subsubsection{Reduction}

This paper use volume of industrial soot(dust) emission, number of industrial enterprises show the relationship between pollutant emissions and industrial scale (Figure 8a), use volume of industrial soot(dust) emission, industrial added value show the relationship between pollutant emissions and industrial output (Figure $8 \mathrm{~b}$ ). On the basis of correlation analysis, two groups of variables' $\mathrm{R}^{2}$ respectively are0.002, 0.608, the group of volume of industrial soot(dust) emission and number of industrial enterprises didn't pass the test, the group of volume of industrial soot(dust) emission, industrial added value through the significant test $99 \%$. Therefore, there is a positive correlation between pollutant emissions and industrial output. Thus, there is no relationship between pollutant emissions and industrial 
scale is line with the spirit of smart growth, there is a positive correlation between pollutant emissions and industrial output is violate the spirit of smart growth.

In this paper, we use ratio of general industrial solid waters comprehensively utilized, number of industrial enterprises show the relationship between pollution control and industrial scale (Figure 9a), use ratio of general industrial solid waters comprehensively utilized, industrial added value show the relationship between pollution control and industrial output (Figure 9b). On the basis of correlation analysis, two groups of variables' $\mathrm{R}^{2}$ respectively are $0.214,0.006$, two groups of variables all didn't pass the significance test. Therefore, there is no relationship between ratio of general industrial solid waters comprehensively utilize and number of industrial enterprises, there is no relationship between ratio of general industrial solid waters comprehensively utilized and industrial added value. Thus, environmental pollutants emission reduction of renewing cities in China is not significantly affected by industrial scale, industrial output. Because the development of different renewing city depend on different resource, so that different resource will lead to different degrees of pollutants. We couldn't judge these two groups whether in line with the spirit of smart growth cause we couldn't judge the ratio of general industrial solid waters comprehensively utilized by the industrial scale and industrial output.

Figure 8. The relationship between volume of industrial soot (dust) emission and related variables.
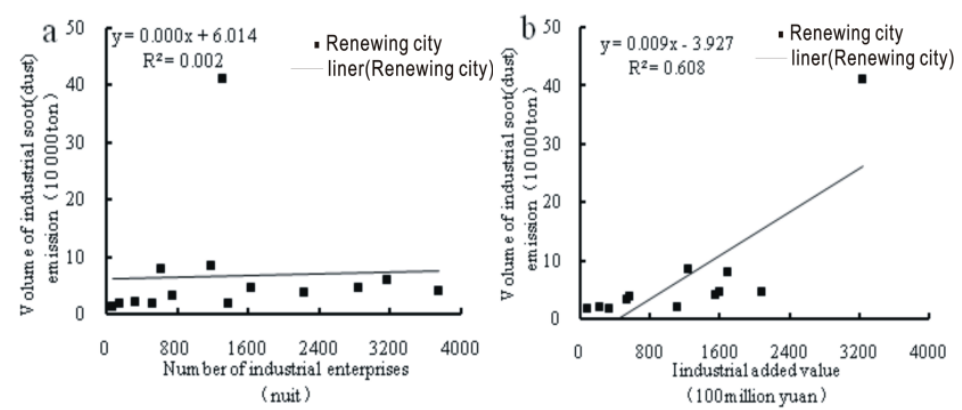

Figure 9. The relationship between ratios of general industrial solid waters comprehensively utilized and related variables.

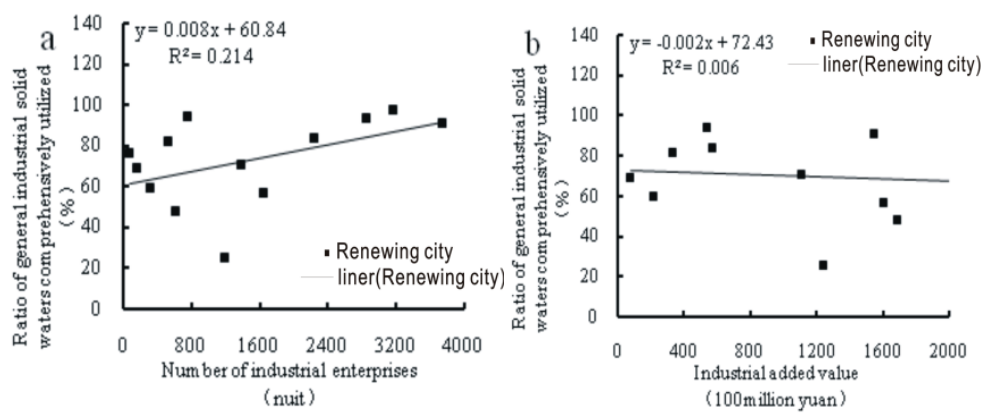

\subsection{Social comfort}

The spirit of smart growth about social comfort including 3 aspects, which are create a positive financial impact, enhance the urban agglomeration forces, improve the quality of life for residents. 
In this paper, use total urban GDP, government fiscal expenditure show the relationship between cities output and government fiscal expenditure (Fig10). On the basis of correlation analysis, the group of variable' $\mathrm{R}^{2}$ is 0.812 , through the significant test $99 \%$. Therefore, there is a positive correlation between the total urban GDP and the city government fiscal expenditure. Thus, the city output increased with increasing fiscal expenditure in renewing city, which is consistent with the smart growth of city government expenditure between GDP and the requirements of the development.

Figure 10. The relationship between gross domestic product disposable and local government general budget expenditure.

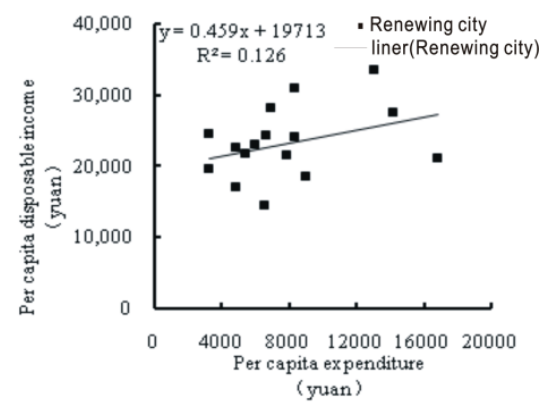

Figure 11. The relationship between per capita income and per budget expenditure.

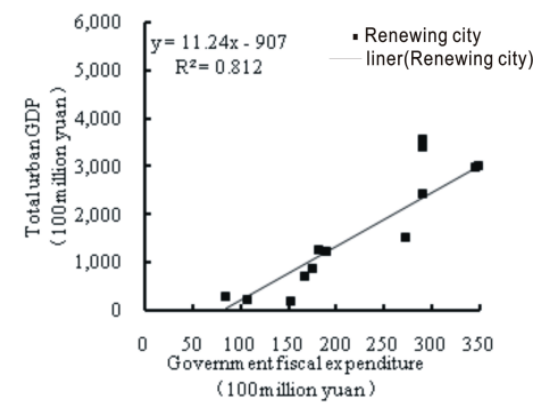

This paper use the per capita disposable income, per capita expenditure show the relationship between cities income level and government fiscal expenditure (Fig11). On the basis of correlation analysis, the group of variable' $\mathrm{R}^{2}$ is 0.126 , not through the significant test. Therefore, there is no relationship between the per capita disposable income and per capita expenditure. Thus, per capita disposable income of the renewing city was less affected by the per capita expenditure. In fact, the government expenditure increase is beneficial in the city construction, it will play an active function to the city economic development, but for the renewing city, the government fiscal expenditure to increase the per capita disposable income and obvious effect, which may be due to too little, industry is in a period of upgrading legacy, history still more serious value of regeneration type city sample, resulting in the government finance investment benefit cannot appear directly in the development of economy, but in general they still showed a positive correlation trend. 


\subsubsection{Enhance the urban agglomeration forces}

Urban agglomeration force mainly includes the city to the various resources such as manpower, capital, information absorption capacity, is subsequent guarantee for the sustainable development of renewing city.

This paper respectively use total urban GDP, foreign investment in actual use show the relationship between cities output and government foreign investment (Fig12a), use total urban GDP, students enrollment of regular institutions of higher show the relationship between cities output and human resources(Fig12b), use total urban GDP, the number of the city's employment industry show the relationship between cities output and employment situation(Fig12c), use total urban GDP, population proportion of tertiary industry show the relationship between cities output and urban industrial development potential (Fig12d), use total urban GDP, technology expenditure show the relationship between cities output and city innovation ability(Fig12e).

On the basis of correlation analysis, the five groups of variable' $\mathrm{R}^{2}$ respectively are $0.235,0.166$, $0.775,0.108,0.484$. Total urban GDP, the number of the city's employment, total urban GDP, technology expenditure through the significant test $95 \%$. Therefore, there is a positive correlation between total urban GDP and the number of the city's employment, there is a positive correlation between total urban GDP and technology expenditure. The correlation between cities output and government foreign investment, urban industrial development potential, human resources is not strong, these three groups of variables is violate to the spirit of smart growth, which are caused by the reasons as follows what are the city industrial structure is still in the escalation in the related industry, low value-added products, the third industry in the traditional service industry, innovation is not strong. However, the output with the city increased the number of employees, increase the fiscal expenditure on science and technology, which is consistent with the requirements of the smart growth.

Figure 12. The relationship between Gross Domestic Product and related variables.

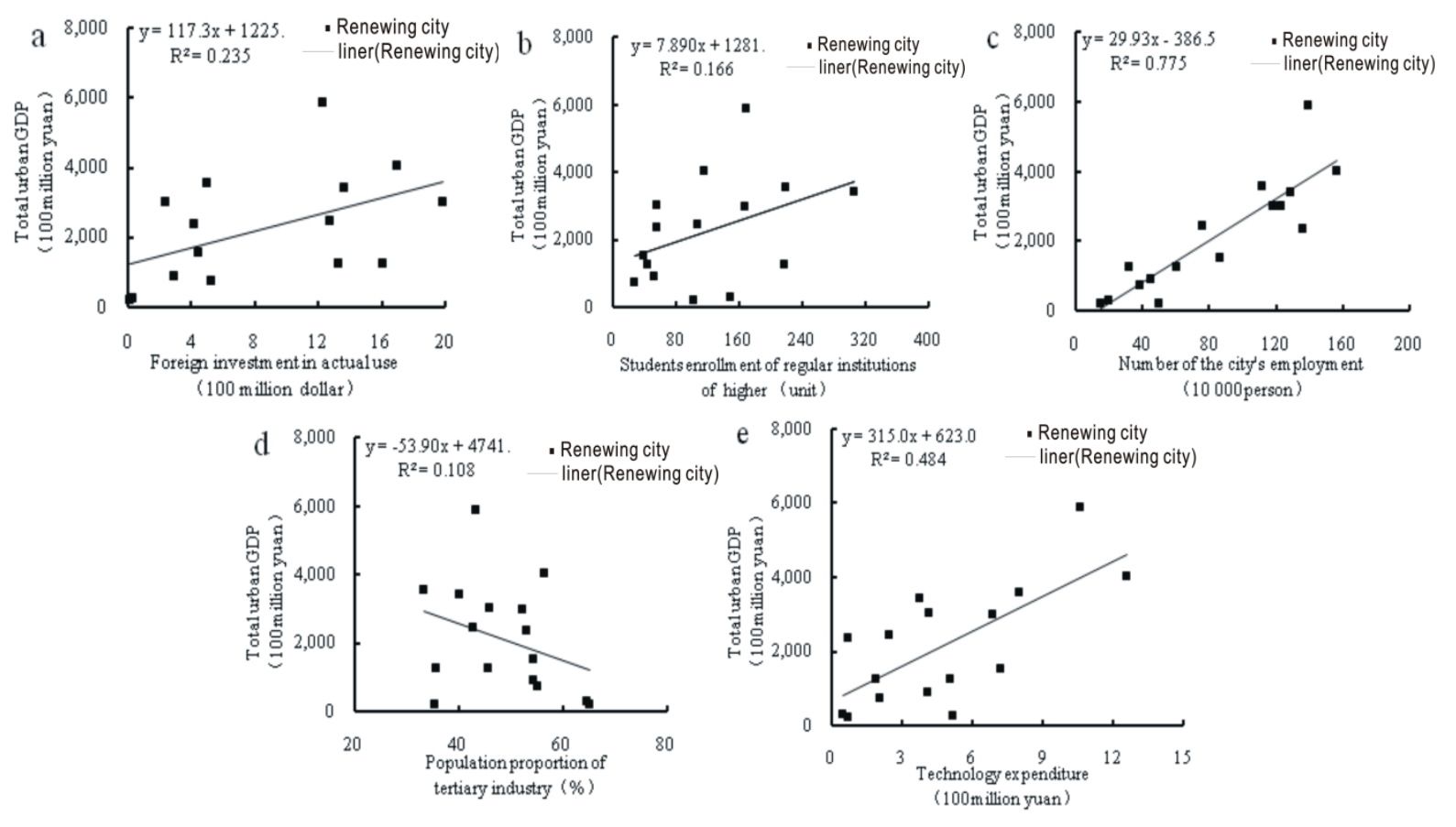


The per capita disposable income from the figures directly reflects the level of urban residents living level. This paper respectively using the per capita disposable income, foreign investment in actual use show the relationship between cities income level and government fiscal expenditure (Figure 13a), use the per capita disposable income, students enrollment of regular institutions of higher education per 10 000 persons show the relationship between cities income level and human resources (Figure 13b), use the per capita disposable income, the number of the city's employment show the relationship between cities income level and employment situation (Figure 13c), use the per capita disposable income, population proportion of tertiary industry show the relationship between cities income level and urban industrial development potential (Figure 13d), use the per capita disposable income, technology expenditure show the relationship between cities income level and city innovation ability (Figure 13e).

On the basis of correlation analysis, the five groups of variable' $\mathrm{R}^{2}$ respectively are $0.209,0.063$, $0.504,0.347,0.027$. In conclusion, the relationship between the per capita disposable income and the proportion of the third industry personnel through the significant test of $99 \%$, but they show the negative correlation. Thus, the correlation between cities income level and government fiscal expenditure, human resources, employment situation, city innovation ability are not strong city. It's worth noting that the per capita disposable income and the third industry personnel employment proportion is inversely proportional to the economic status of the residents, that decreases with the increasing of the city's third industry personnel employment proportion, this conclusion is violate to the spirit of smart growth.

Figure 13. The relationship between per capita disposable income and related variables.

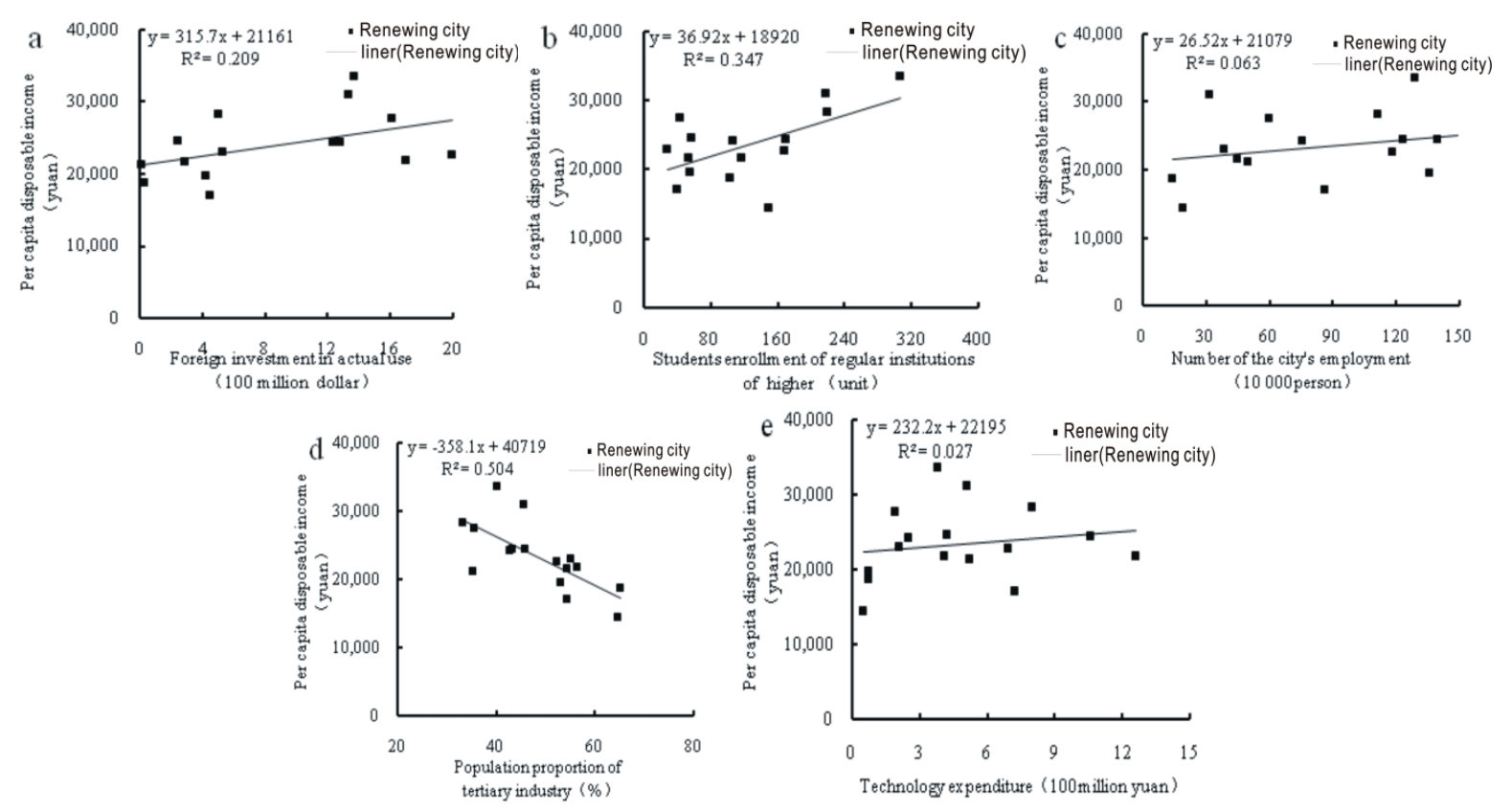

3.3.3 Improve the quality of life for residents

The basic guarantee of the quality of life of city residents mainly include medical, education and employment, at the same time, rich and colorful cultural and recreational activities is one of the eternal charm of city life

First of all, this paper use the number of students in compulsory, education expenditure show the relationship between educational services supply and government fiscal expenditure (Figure 14). On the 
basis of correlation analysis, the groups of variable' $\mathrm{R}^{2}$ is 0.551 , through the significant test $99 \%$. Therefore, there is positively correlation between the number of students in compulsory education, government fiscal expenditure, which is present that the financial education expenditure increases 100000000 yuan each, the number of compulsory education students could add 12000 people. This conclusion in line with the spirit of smart growth for residents of the compulsory education.

Figure 14. The relationship between students' enrollment of regular institutions of higher education per 10000 persons and related variables.

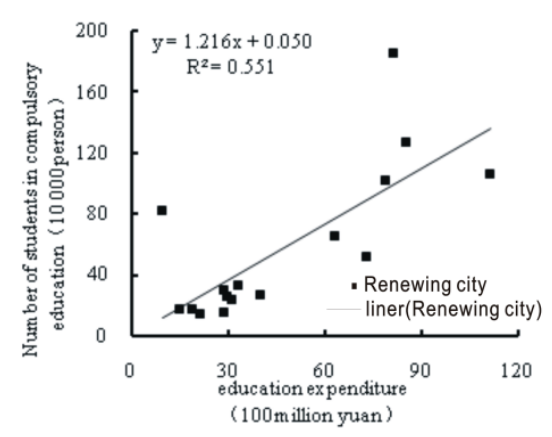

Secondly, this paper use number of beds of hospital and health centers, the total urban population show the relationship between medical supply of public services and population (Figure 15a), use number of beds of hospital and health centers, industrial added value show the relationship between medical supply of public services and industrial output (Figure 15b). On the basis of correlation analysis, the two groups of variable' $\mathrm{R}^{2}$ respectively are $0.897,0.686$, through the significant test $99 \%$. Therefore, there is a positive correlation between number of beds of hospital and health centers and the total urban population, there is a positive correlation between number of beds of hospital and health centers and industrial added value. Thus, medical public service as the city population size, industrial added value increased. It's further to prove that the second stage of labor is still the dominant industry of industrial economic development in the renewing city, city economy driven by the development of industry, and then promote the city medical expenditure, in final, develop the medical industry. This route of development is in line with the spirit of smart growth.

Figure 15. The relationship between number of beds of hospital and health centers (bed) and related variables.
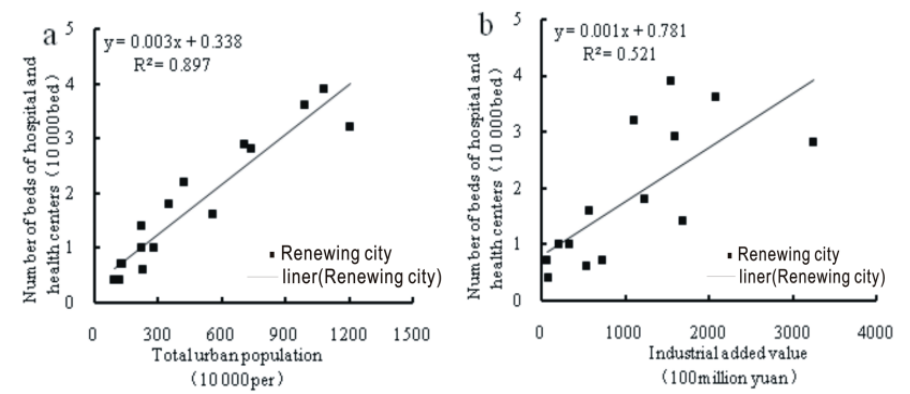

What's more, use persons covered by basic pension insurance, municipality's total population show the relationship between social security and population (Figure 16a), use persons covered by basic 
pension insurance, industrial added value show the relationship between social security and industrial output (Figure 16b). On the basis of correlation analysis, the two groups of variable' $\mathrm{R}^{2}$ respectively are $0.733,0.914$, through the significant test $99 \%$. Therefore, there is a positive correlation between persons covered by basic pension insurance and municipality's total population, there is a positive correlation between persons covered by basic pension insurance, industrial added value show the relationship between social security and industrial output. Thus, social security ability increased with the increase of municipal district population scale, the industrial added value improvement. This is related to industrial structure still is given priority to with industrial, which is conforms to the requirements of smart growth.

Figure 16. The relationship between persons covered by basic pension insurance and related variables.
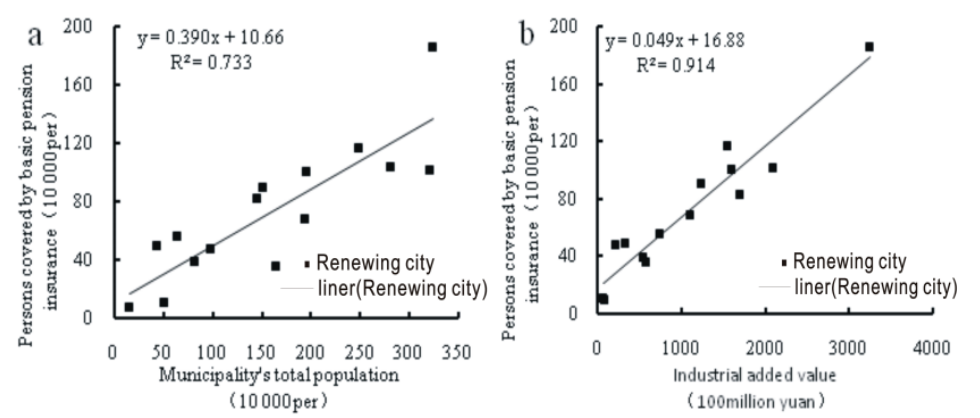

In the end, this paper use collection of public libraries per 100 persons, the total urban population show the relationship between cultural richness and population (Figure 17a), use collection of public libraries per 100 persons, total urban GDP show the relationship between cultural richness and cities output (Figure 17b). On the basis of correlation analysis, the two groups of variable' $\mathrm{R}^{2}$ respectively are $0.284,0$, the two groups of variable are not pass the significance test. Therefore, there is no relationship between collection of public libraries per 100 persons and the total urban population, there is no relationship between collection of public libraries per 100 persons and total urban GDP. Thus, there is no relationship between the cultural life of and the urban population size, cities output, which is violate to the spirit of smart growth.

Figure 17. The relationship between persons collection of public libraries per 100 persons and related variables.
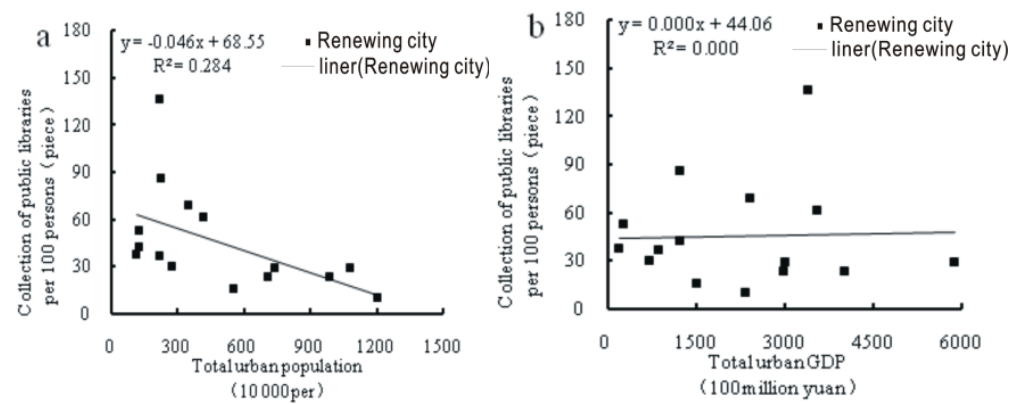


\section{Conclusions and suggestions}

\subsection{Smart growth research results of renewing city}

On the basis of the smart growth analysis frame, this paper from the city of the appropriate exploitation and green ecological and social comfort of the three aspects of China's 16 renewing cities growth status of inspection. As shown in Table 2, smart growth analysis framework consists of 40 groups of relationship among the variables, the need to examine whether relevance, has what kind of relationship between variables, and whether this relationship in line with the "smart growth" advocated by the spirit and the pursuit of the goal. Through the statistics of the existing data description and regression analysis, in the 40 set of variables, a total of the relationship between the 22 variables or no correlation in line with the smart growth, the lack of a relationship between 15 groups of variables or relationship between violating the smart growth principle, another 3 groups of relationship among variables also unable to determine whether it is consistent with the smart growth.

Table 2. The test results of smart growth for renewing city in China

\begin{tabular}{|c|c|c|c|c|}
\hline & Study content & Correlation & Smart & Not smart \\
\hline \multirow{12}{*}{$\begin{array}{l}\text { Moderate } \\
\text { exploitation }\end{array}$} & $\begin{array}{l}\text { The relationship between infrastructure and } \\
\text { population }\end{array}$ & NO correlation & & $x$ \\
\hline & $\begin{array}{l}\text { The relationship between infrastructure and } \\
\text { industry structure }\end{array}$ & NO correlation & \multicolumn{2}{|c|}{ uncertain } \\
\hline & $\begin{array}{l}\text { The relationship between infrastructure and } \\
\text { employment density }\end{array}$ & NO correlation & \multicolumn{2}{|l|}{$\sqrt{ }$} \\
\hline & $\begin{array}{l}\text { The relationship between land development } \\
\text { and population }\end{array}$ & $\begin{array}{l}\text { The liner } \\
\text { correlation }\end{array}$ & \multicolumn{2}{|l|}{$\sqrt{ }$} \\
\hline & $\begin{array}{l}\text { The relationship between land development } \\
\text { and industry structure }\end{array}$ & NO correlation & \multicolumn{2}{|l|}{$\sqrt{ }$} \\
\hline & $\begin{array}{l}\text { The relationship between land development } \\
\text { and employment density }\end{array}$ & NO correlation & \multicolumn{2}{|l|}{$\sqrt{ }$} \\
\hline & $\begin{array}{l}\text { The relationship between land development } \\
\text { and income level }\end{array}$ & NO correlation & \multicolumn{2}{|l|}{$\sqrt{ }$} \\
\hline & $\begin{array}{l}\text { The relationship between the number of publis } \\
\text { transport supply and population }\end{array}$ & NO correlation & \multicolumn{2}{|l|}{$\sqrt{ }$} \\
\hline & $\begin{array}{l}\text { The relationship between the number of publis } \\
\text { transport supply and the population density }\end{array}$ & NO correlation & & $x$ \\
\hline & $\begin{array}{l}\text { The relationship between the public transport } \\
\text { carrying capacity and population }\end{array}$ & $\begin{array}{l}\text { The liner } \\
\text { correlation }\end{array}$ & \multicolumn{2}{|l|}{$\sqrt{ }$} \\
\hline & $\begin{array}{l}\text { The relationship between the public transport } \\
\text { carrying capacity and the population density }\end{array}$ & $\begin{array}{l}\text { Exponential } \\
\text { correlation }\end{array}$ & \multicolumn{2}{|l|}{$\sqrt{ }$} \\
\hline & $\begin{array}{l}\text { The relationship between the urban housing } \\
\text { land area and population }\end{array}$ & $\begin{array}{l}\text { The liner } \\
\text { correlation }\end{array}$ & \multicolumn{2}{|l|}{$\sqrt{ }$} \\
\hline \multirow{8}{*}{$\begin{array}{l}\text { Green } \\
\text { ecology }\end{array}$} & $\begin{array}{l}\text { The relationship between the green covered } \\
\text { area and population }\end{array}$ & NO correlation & $\sqrt{ }$ & \\
\hline & $\begin{array}{l}\text { The relationship between the green covered } \\
\text { area and land development }\end{array}$ & NO correlation & $\sqrt{ }$ & \\
\hline & $\begin{array}{l}\text { The relationship between cities output and } \\
\text { total water consumption }\end{array}$ & $\begin{array}{l}\text { The liner } \\
\text { correlation }\end{array}$ & & $x$ \\
\hline & $\begin{array}{l}\text { The relationship between cities output and } \\
\text { total gas consumption }\end{array}$ & $\begin{array}{l}\text { The liner } \\
\text { correlation }\end{array}$ & & $\times$ \\
\hline & $\begin{array}{l}\text { The relationship between cities output and } \\
\text { total electricity consumption }\end{array}$ & $\begin{array}{l}\text { The liner } \\
\text { correlation }\end{array}$ & & $x$ \\
\hline & $\begin{array}{l}\text { The relationship between pollutant emissions } \\
\text { and industrial scale }\end{array}$ & NO correlation & \multicolumn{2}{|l|}{$\sqrt{ }$} \\
\hline & $\begin{array}{l}\text { The relationship between pollutant emissions } \\
\text { and industrial output }\end{array}$ & NO correlation & & $\times$ \\
\hline & $\begin{array}{l}\text { The relationship between pollution control anc } \\
\text { industrial scale }\end{array}$ & NO correlation & \multicolumn{2}{|c|}{ uncertain } \\
\hline
\end{tabular}




\begin{tabular}{|c|c|c|c|c|}
\hline & $\begin{array}{l}\text { The relationship between pollution control an } \\
\text { industrial output }\end{array}$ & NO correlation & uncertair & \\
\hline \multirow{19}{*}{$\begin{array}{l}\text { Social } \\
\text { comfort }\end{array}$} & $\begin{array}{l}\text { The relationship between cities output and } \\
\text { government fiscal expenditure }\end{array}$ & The liner correlation $\sqrt{ }$ & & \\
\hline & $\begin{array}{l}\text { The relationship between cities income level } \\
\text { and government fiscal expenditure }\end{array}$ & NO correlation & $\sqrt{ }$ & \\
\hline & $\begin{array}{l}\text { The relationship between cities output and } \\
\text { government foreign investment }\end{array}$ & NO correlation & & $x$ \\
\hline & $\begin{array}{l}\text { The relationship between cities output and } \\
\text { human resources }\end{array}$ & NO correlation & & $x$ \\
\hline & $\begin{array}{l}\text { The relationship between cities output and } \\
\text { employment situation }\end{array}$ & $\begin{array}{l}\text { The liner } \\
\text { correlation }\end{array}$ & $\sqrt{ }$ & \\
\hline & $\begin{array}{l}\text { The relationship between cities output and } \\
\text { urban industrial development potential }\end{array}$ & NO correlation & & $x$ \\
\hline & $\begin{array}{l}\text { The relationship between cities output and city } \\
\text { innovation ability }\end{array}$ & $\begin{array}{l}\text { The liner } \\
\text { correlation }\end{array}$ & $\sqrt{ }$ & \\
\hline & $\begin{array}{l}\text { The relationship between cities income level } \\
\text { and government fiscal expenditure }\end{array}$ & NO correlation & & $x$ \\
\hline & $\begin{array}{l}\text { The relationship between cities income level } \\
\text { and human resources }\end{array}$ & NO correlation & $\sqrt{ }$ & \\
\hline & $\begin{array}{l}\text { The relationship between cities income level } \\
\text { and employment situation }\end{array}$ & NO correlation & & $x$ \\
\hline & $\begin{array}{l}\text { The relationship between cities income level } \\
\text { and urban industrial development potential }\end{array}$ & $\begin{array}{l}\text { The liner } \\
\text { correlation }\end{array}$ & & $x$ \\
\hline & $\begin{array}{l}\text { The relationship between cities income level } \\
\text { and city innovation ability }\end{array}$ & NO correlation & & $x$ \\
\hline & $\begin{array}{l}\text { The relationship between educational services } \\
\text { supply and government fiscal expenditure }\end{array}$ & $\begin{array}{l}\text { The liner } \\
\text { correlation }\end{array}$ & $\sqrt{ }$ & \\
\hline & $\begin{array}{l}\text { The relationship between medical supply of } \\
\text { public services and population }\end{array}$ & $\begin{array}{l}\text { The liner } \\
\text { correlation }\end{array}$ & $\sqrt{ }$ & \\
\hline & $\begin{array}{l}\text { The relationship between medical supply of } \\
\text { public services and industrial output }\end{array}$ & $\begin{array}{l}\text { The liner } \\
\text { correlation }\end{array}$ & $\sqrt{ }$ & \\
\hline & $\begin{array}{l}\text { The relationship between Social Security and } \\
\text { population }\end{array}$ & $\begin{array}{l}\text { The liner } \\
\text { correlation }\end{array}$ & $\sqrt{ }$ & \\
\hline & $\begin{array}{l}\text { The relationship between Social Security and } \\
\text { industrial output }\end{array}$ & $\begin{array}{l}\text { The liner } \\
\text { correlation }\end{array}$ & $\sqrt{ }$ & \\
\hline & $\begin{array}{l}\text { The relationship between Cultural richness an } \\
\text { population }\end{array}$ & NO correlation & & $x$ \\
\hline & $\begin{array}{l}\text { The relationship between Cultural richness an } \\
\text { cities output }\end{array}$ & NO correlation & & $x$ \\
\hline
\end{tabular}

\subsection{Sugesstion}

Based on the results of the analysis, there are 14 groups of variables are not in line with the path of smart growth for renewing city, which can be explained from aspects of city infrastructure supply, land development and utilization, energy saving and emission reduction, environmental protection and city agglomeration promotion. The above 4 aspects are the keys that government of the renewing city should focus on as well.

Firstly, strengthen infrastructure and public transportation supply. The renewing city in the supply of infrastructures and public transportation are not as the urban population scale growth changed significantly, which is highly correlated with the development of urban economy, government fiscal expenditure. City economic rapid development is bound to attract more people, the change of the population will accelerate the city infrastructure construction, economic development will increase the government's fiscal expenditure, the above relationship going to be the benign interaction. In this paper, the empirical analysis found that there is no relationship between city public traffic supply the scale of the population, on the contrary, there is a positive relationship between the traffic carrying capacity and population scale formation. Thus can judge that when the scale of population go increase quickly, the number of public traffic has not been improved significantly. In order to cope with the rapid development 
of the city, the government can only rely on upgrading its carrier density and operating frequency. It will lead crowding when passengers on public transport so that it will hinder the promotion of public transport. Therefore, the government should increase financial expenditure input from its infrastructure and public transport supply for renewing city.

Secondly, for reasonable exploitation and utilization of the land, which is including development of the city built-up area and the development of residential land. How in the growing population of circumstances, to try to reduce the farmland, green spaces and other damage, do not contain the premise in normal development of city needs, does not affect the demand for reasonable living residents, strike a balance between land development and protection of land resources, it is a realistic problem faced by renewing city. We can't judge when the smart growth inflection point will appear about the positive correlation between land development and population caused by the amount of data is relatively small study, which requires government to formulate strict land planning and approval system, do a good job in judgment city industrial development and the size of the population trend index, the timely development of land for various kinds of the rational development of city land. For residential land, the government must make the establishment of different housing supply system provided to different income groups in different stage of urbanization. Establishing a perfect coordination of affordable housing and low rent housing plan is the plan to meet the various classes, especially the fundamental guarantee for low-income families.

Thirdly, promote energy-saving emission reduction and environmental protection city. Environmental protection and energy saving and emission reduction are an important tasks for the development of renewing city, the government should put them into the equal important position which compare with the development of economic. The empirical analysis found that there is positive correlation between the growth of GDP for renewing city and the consumption of energy, which is not in conformity with the spirit of smart growth. Although this result may be due by the reasons as follow, renewing city is still in the stage of transformation, city economic development is still mainly rely on the industry, the whole industry chain also did not upgrade is completed, resulting in highly dependent phenomenon of energy. In one word, the method of successful for renewing city must pay attention to the following aspects: for the enterprise, to the integration and application of new technology, accelerate the pace of industrial upgrading, reduce waste emissions, to strive for the recycling of resources; for the government, to control city industrial development, abandon the backward technology, serious pollution, low output of the industry strongly, for the re-employment of personnel to provide free job training, to ensure social stability; for individuals, we should start with small, less waste a drop of water, once the electricity, to develop good resources, energy use habits.

Fourthly, enhance the city aggregation ability. The empirical analysis found that there is no relationship between cities output and residents' income, foreign investment, population proportion of tertiary industry, which reflects the situation of industry is extremely uneven distribution for renewing city. The tertiary industry as the traditional service industries of renewing city, which is highly dependent on the second industry, the city's tertiary industry lack of creativity, challenge, technical, almost no competitive advantage, which play a auxiliary role for the development of renewing city. This fragile tertiary industry is extremely unfavorable for city transformation. The government should guide the development of the tertiary industry, relying on the local accumulation of resources, investment, through the development of tourism, finance, transportation, exhibition services or science and technology 
research and development institutions and other different industries, to attract capital and human resource accumulation, to accelerate the promotion of comprehensive value of regeneration type city of the third industry.

\section{References}

1. Zhu Ming-feng. The inflexion point theory and its significance in the development of resource-based cities. Resource Survey \& Environment, 2006, 27(1):12-17.

2. Cao, Fei; Liu, Xuemin. Study on Economic transformation of resource-based cities: A case study of Zaozhuang. Urban Studies, 2012, 19(2):32-41.

3. Liu, Xuemin. Study on the development of uncertainty in resource-exhausted cities. Urban Problems, 2011(5):9-11.

4. Liu, Xuemin. Study on transformation of resource-based cities. Macroeconomics, 2009(10):18-20.

5. Tan, Jing; Chen, Xu. Study on the compare with the smart growth and the sustainable development. Economic Forum, 2009(2):58-59.

6. Ingram, Gregory K.; Carbonell, Armando. Smart Growth Policies: An Evaluation of Programs and Outcomes. Lincoln Institute of Land Policy: Lincoln, USA; p.12-15.

7. Guan, Jing. Research on the Smart Growth of Chinese Megacity. JiLin University: Changchun, China, 2013.

(C) 2015 by the authors; licensee MDPI and IFoU, This article is an open access article distributed under the terms and conditions of the Creative Commons Attribution license. 